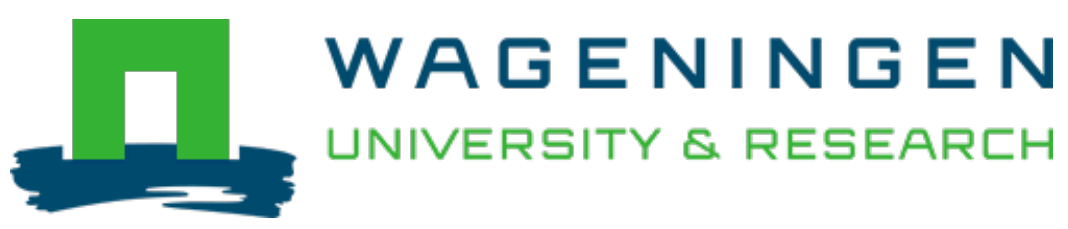

\title{
Impact of brewing process operations on phytate, phenolic compounds and in vitro solubility of iron and zinc in opaque sorghum beer
}

\author{
Food Science and Technology = Lebensmittel-Wissenschaft und Technologie \\ Kayodé, A.P.P.; Hounhouigan, J.D.; Nout, M.J.R. \\ https://doi.org/10.1016/j.lwt.2006.04.001
}

This publication is made publicly available in the institutional repository of Wageningen University and Research, under the terms of article $25 \mathrm{fa}$ of the Dutch Copyright Act, also known as the Amendment Taverne. This has been done with explicit consent by the author.

Article 25 fa states that the author of a short scientific work funded either wholly or partially by Dutch public funds is entitled to make that work publicly available for no consideration following a reasonable period of time after the work was first published, provided that clear reference is made to the source of the first publication of the work.

This publication is distributed under The Association of Universities in the Netherlands (VSNU) 'Article $25 \mathrm{fa}$ implementation' project. In this project research outputs of researchers employed by Dutch Universities that comply with the legal requirements of Article $25 \mathrm{fa}$ of the Dutch Copyright Act are distributed online and free of cost or other barriers in institutional repositories. Research outputs are distributed six months after their first online publication in the original published version and with proper attribution to the source of the original publication.

You are permitted to download and use the publication for personal purposes. All rights remain with the author(s) and / or copyright owner(s) of this work. Any use of the publication or parts of it other than authorised under article $25 \mathrm{fa}$ of the Dutch Copyright act is prohibited. Wageningen University \& Research and the author(s) of this publication shall not be held responsible or liable for any damages resulting from your (re)use of this publication.

For questions regarding the public availability of this publication please contact openscience.library@wur.nl 


\title{
Impact of brewing process operations on phytate, phenolic compounds and in vitro solubility of iron and zinc in opaque sorghum beer
}

\author{
A.P.P. Kayodéa ${ }^{\text {, J.D. Hounhouigan }}{ }^{\mathrm{a}}$, M.J.R. Nout ${ }^{\mathrm{b}, *}$ \\ ${ }^{a}$ Faculté des Sciences Agronomiques, Université d'Abomey-Calavi, 01 BP 526 Cotonou, Bénin \\ ${ }^{\mathrm{b}}$ Department of Agrotechnology and Food Sciences, Laboratory of Food Microbiology, Wageningen University, \\ P.O. Box 8129, 6700 EV Wageningen, The Netherlands
}

Received 15 November 2005; received in revised form 29 March 2006; accepted 4 April 2006

\begin{abstract}
Opaque sorghum beer is a significant component of the diet of millions of poor people in rural Africa. This study reports the effect of traditional brewing operations on its level of micronutrients, especially iron and zinc. The example of a West African sorghum beer, tchoukoutou, in Northern Benin was studied. The beer was characterized and the impact of process unit operations on phytate, phenolic compounds, and $\mathrm{Zn}$ and $\mathrm{Fe}$ in vitro solubility was evaluated. The major microorganisms involved in the beer fermentation were Saccharomyces cerevisiae and heterofermentative lactobacilli. The manufacturing process reduces the phytate content by nearly $95 \%$, particularly during germination, mashing-boiling and fermentation. The level of reactive phenolic groups increased as a result of germination and fermentation as well as from a shift in dry matter composition. Simultaneously with these modifications, an increase of Fe solubility was observed, and a correlation between phytate and Fe solubility $\left(R^{2}=0.85\right)$ was established. No clear correlation could be established between the $\mathrm{Zn}$ solubility and the phytate content of the products. During beer manufacturing, significant losses of minerals occur particularly during soaking and mashing/filtration; thus the quantity of minerals available to consumers is restricted. Improvements aiming to minimize such losses are highly desirable.
\end{abstract}

(C) 2006 Swiss Society of Food Science and Technology. Published by Elsevier Ltd. All rights reserved.

Keywords: Sorghum; Brewing; Tchoukoutou; Solubility; Iron; Zinc

\section{Introduction}

Iron $(\mathrm{Fe})$ and zinc $(\mathrm{Zn})$ deficiencies are a major public health problem in developing countries. Chronic micronutrient deficiencies, particularly of $\mathrm{Fe}$ and $\mathrm{Zn}$, cause child mortality, impaired mental and physical development, decreased work output, and contribute to morbidity from infections (Dossa, Ategbo, de Koning, van Raaij, \& Hautvast, 2001; Gibson, 1994; Oikeh, Menkir, MaziyaDixon, Welch, \& Glahn, 2003). Therefore, an increase of bioavailable $\mathrm{Fe}$ and $\mathrm{Zn}$ in the indigenous diets is highly desirable.

Opaque sorghum beers are popular alcoholic beverages in Africa. In the West Africa region they are known as tchoukoutou in Benin, dolo in Burkina-Faso, pito in Ghana,

\footnotetext{
${ }^{*}$ Corresponding author. Tel.: + 31317482834 ; fax: +31317484978

E-mail address: rob.nout@wur.nl (M.J.R. Nout).
}

and burukutu or otika in Nigeria (Kayodé, Adégbidi, Linnemann, Nout, \& Hounhouigan, 2005; Odunfa, 1985). The beers have a sour taste, a relatively high dry matter

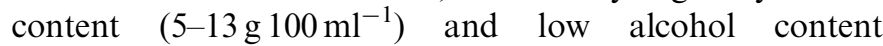
(2-3 $\left.\mathrm{ml} \mathrm{l} 100 \mathrm{ml}^{-1}\right)$, which make them suitable beverages for adults and teenagers (Agu \& Palmer, 1998; Briggs, Boulton, Brookes, \& Stevens, 2004). They are largely consumed by the poorest people and significantly contribute to the diet of millions of consumers. The beers are mostly prepared with Guinea corn (Sorghum bicolor) but other cereals such as millet or maize can be used as adjunct or as substitutes (Kayodé et al., 2005). The manufacturing process consists of malting (soaking, germination, sun drying), brewing (mashing, boiling, filtration) and fermentation. Depending on the geographic location, variations may occur in the process (Haggblade \& Holzapfel, 1989; Odunfa, 1985).

The nutritional attributes of eight commercial sorghum beers have been reported by Novellie and De Schaepdrijver 
(1986) as follows: protein $5.4 \mathrm{gl}^{-1}$, ash $1.13 \mathrm{gl}^{-1}$, carbohydrate $47.6 \mathrm{gl}^{-1}$, iron $(\mathrm{Fe}) 1.4 \mathrm{gl}^{-1}$ and zinc $(\mathrm{Zn}) 1.4 \mathrm{gl}^{-1}$. This suggests that such beer can significantly contribute to macronutrient supply to the diet, considering the rather large quantity that is consumed daily in certain locations (Briggs et al., 2004; Kayodé et al., 2005). At present, little information is available on the micronutrient availability in African opaque beers. The unit process operations (e.g. soaking, germination and fermentation) involved in the preparation of opaque sorghum beers have been reported to reduce the levels of phytate, a major inhibitor of Fe and Zn availability (Graf, 1986; Mahgoub \& Elhag, 1998; Traoré, Mouquet, Icard-Vernière, Traoré, \& Trèche, 2005). In addition, several studies demonstrated that germination and fermentation affect condensed phenolic compounds (PC) (Bvochora, Danner, Miyafuji, Braun, \& Zvauya, 2005; Obizoba \& Atii, 1991; Subramanian, Murty, Sambasiva, \& Jambunathan, 1992) which also reduce mineral bioavailability by chelation. Thus, considering the prominent role of germination and fermentation in the process, increased solubility of $\mathrm{Fe}$ and $\mathrm{Zn}$ could be expected in indigenous African beers.

The present study was conducted to characterize tchoukoutou, the major opaque sorghum beer of Benin and to assess the impact of the different process unit operations of tchoukoutou making on phytate, $\mathrm{PC}$ and $\mathrm{Fe}$ and $\mathrm{Zn}$ in vitro solubility, as an index for their bioavailability.

\section{Materials and methods}

\subsection{Processing and sampling}

The processing trials took place in Parakou, a small town in the northern region of Benin, where tchoukoutou is commonly produced and consumed. Three batches of red sorghum grain, selected and purchased by processors from a local market, were processed into tchoukoutou at three commercial production sites according to the traditional brewing practices, as follows. On average, $27 \mathrm{~kg}$ of grain were soaked overnight at room temperature (Processor 1: $9 \mathrm{~h}$, Processor 2: $11 \mathrm{~h}$, Processor 3: $12 \mathrm{~h}$ ), germinated (P1: $85 \mathrm{~h}, \mathrm{P} 2: 74 \mathrm{~h}, \mathrm{P} 3: 72 \mathrm{~h}$ ), sun-dried at ambient temperature of about $30-37^{\circ} \mathrm{C}(\mathrm{P} 1: 15 \mathrm{~h}, \mathrm{P} 2: 15 \mathrm{~h}, \mathrm{P} 3: 7 \mathrm{~h})$, ground in a disc mill, mashed in water by gradually heating until the boiling point was reached after $2 \mathrm{~h}$, soured during an overnight rest, filtered, boiled (P1: 9h, P2: $8 \mathrm{~h}, \mathrm{P} 3: 6 \mathrm{~h})$, cooled, inoculated and fermented overnight $(\mathrm{P} 1: 13 \mathrm{~h}, \mathrm{P} 2$ : $14 \mathrm{~h}, \mathrm{P} 3 \mathrm{:} 13 \mathrm{~h}$ ). These ranges of values for processing parameters, may lead to fluctuation in data. We highlighted this by expressing values as means with standard deviation. At the end of the fermentation, beer samples were collected in screw-capped bottles, packed in an insulated icebox, transported to the laboratory and analysed immediately for yeasts and lactic acid bacteria (LAB) content (Hounhouigan, Nout, Nago, Houben, \& Rombouts, 1993). The remaining beer samples were freeze- dried and stored at $-20{ }^{\circ} \mathrm{C}$ for further analyses. In addition, samples were withdrawn from each process step, dried in an oven, ground in a Retsch mill (type ZM 1, Retsch, Haan, Germany) fitted with a $0.5 \mathrm{~mm}$ screen and stored at $-20^{\circ} \mathrm{C}$ until analysis.

\subsection{Microbiological analysis}

Duplicate samples of tchoukoutou $(10 \mathrm{ml})$ were diluted in $90 \mathrm{ml}$ sterile peptone physiological saline solution $(5 \mathrm{~g}$ peptone, $8.5 \mathrm{~g} \mathrm{NaCl}$, and $1000 \mathrm{ml}$ distilled water, $\mathrm{pH}=7.0$ ) and homogenized with a Stomacher lab-blender (type 400, London, UK). Decimal dilutions were plated. Total counts of aerobic mesophilic bacteria (TC), LAB, yeasts and Enterobacteriaceae were enumerated as described by Hounhouigan et al. (1993).

The characterization of LAB was performed as follows. Representative colonies of LAB were randomly picked from higher dilutions and purified by successive subculturing on de Man Rogosa and Sharpe Agar (MRSA, CM 361, Oxoid, Hampshire, England) containing $1 \mathrm{gl}^{-1}$ natamycin (Delvocid, DSM, The Netherlands) with incubation in anaerobic jar (Anaerocult A, Merck KGaA, Germany). The isolates were tested for cell morphology, Gram stain, catalase and oxydase reactions. Gas production from glucose was tested after incubation at $30^{\circ} \mathrm{C}$ for $48 \mathrm{~h}$ in MRS broth (CM 359, Oxoid, Hampshire, England). Growth tests were performed at $15^{\circ} \mathrm{C}$ for $5 \mathrm{~d}$ and $45^{\circ} \mathrm{C}$ for $1 \mathrm{~d}$ in MRS broth. Carbohydrate metabolism of isolates was tested on API $50 \mathrm{CH}$ strips with API $50 \mathrm{CHL}$ medium (BioMérieux, Lyon, France) following the manufacturer's instructions. The identification of LAB was done using the IBIS software (Intelligent Bacteria Identification System, The Netherlands) (Wijtzes, Bruggeman, Nout, \& Zwietering, 1997).

For yeasts identification, isolates representing the three production sites were purified by successive sub-culturing on malt extract agar (MEA, CM 59, Oxoid). Preliminary confirmation was based on microscopic observation. The isolates were tested for the fermentation of sucrose, lactose, glucose and raffinose, as well as the assimilation of selected nitrogen sources, i.e. nitrate, ethylamine, L-lysine, cadaverine, and creatine. The assimilation of carbon sources was performed using API 20 C AUX strips (BioMérieux, Lyon, France) according to the manufacturer's instructions. The Diazonium Blue B reaction, a test to differentiate between ascomycetous and basidiomycetous yeasts, was performed as described by Kurtzman, Boekhout, Robert, Fell, and Deak (2003). The on-line available software (http:// www.cbs.knaw.nl) of the Centraalbureau voor Schimmelcultures, Utrecht, the Netherlands was used for yeasts identification.

\subsection{In vitro digestion of samples}

Step 1-the enzymatic degradation - of the in vitro digestion method described by Kiers, Nout, and Rombouts 
(2000) was used. Duplicate dry samples of flour $(5 \mathrm{~g})$ were suspended in $30 \mathrm{ml}$ distilled water and digested under simulated gastro-intestinal conditions, subsequently using $\alpha$-amylase solution (Sigma A-1031), stomach medium consisting of lipase (Amano Pharmaceuticals, Rhizopus F-AP15) and pepsin (Sigma P-6887), and pancreatic solution consisting of pancreatin (Sigma P-1750) and bile (Sigma B-3883). After digestion, the suspension was centrifuged at $3600 \mathrm{~g}$ for $15 \mathrm{~min}$ at $4{ }^{\circ} \mathrm{C}$. The supernatant was decanted and the pellet was washed twice in $20 \mathrm{ml}$ of distilled water and centrifuged. The supernatants were pooled and filtered through a $0.45 \mu \mathrm{m}$ pore filter. A blank was included consisting of $30 \mathrm{ml}$ distilled water digested and filtered as described above. Both filtered supernatants from sample and blank were analysed for $\mathrm{Fe}$ and $\mathrm{Zn}$. Samples were corrected for added reagents/water by subtracting $\mathrm{Fe}$ and $\mathrm{Zn}$ content of blank from that of supernatants from samples. The amounts of $\mathrm{Fe}$ and $\mathrm{Zn}$ (expressed as $\mathrm{mg} \mathrm{kg}^{-1}$ of digested sample) in supernatant were regarded as soluble minerals. Percentage of soluble mineral was calculated as: solubility ratio $=[(\mathrm{Fe}$ or $\mathrm{Zn}$ in supernatant $-\mathrm{Fe}$ or $\mathrm{Zn}$ in blank $) /(\mathrm{Fe}$ or $\mathrm{Zn}$ in undigested sample) $] \times 100$.

\subsection{Chemical analysis}

\subsubsection{Fe and $\mathrm{Zn}$ determination}

Approximately $0.4 \mathrm{~g}$ of flour was digested using hydrofluoric acid $\left(40 \mathrm{gl}^{-1}\right)$ and concentrated nitric acid $\left(650 \mathrm{~g} \mathrm{~kg}^{-1}\right)$ (Novozamsky, van Eck, Houba, \& van der Lee, 1996). Next, the concentrations of Fe and $\mathrm{Zn}$ were analysed by Inductively Coupled Plasma-Optical Emission Spectrometer (ICP-OES, Elan 6000, Perkin-Elmer, USA) (Temminghof, 2000). Samples from in vitro digestion were collected in tubes $(10 \mathrm{ml})$ and $0.15 \mathrm{ml}$ of concentrated nitric acid was added to preserve them. These samples were analysed by the Inductively Coupled Plasma-Mass Spectrometer (ICP-MS, Elan 6000, Perkin-Elmer, USA). Measurements were performed in duplicate.

\subsubsection{Phytate determination}

Approximately $10 \mathrm{mg}$ of grain flour was extracted with $1 \mathrm{ml}$ of $18.2 \mathrm{~g} \mathrm{l}^{-1} \mathrm{HCl}$ containing $50 \mathrm{mg}^{-1}$ cis-aconitate (internal standard) (Bentsink, Yuan, Koornneef, \& Vreugdenhil, 2003). The mixture was boiled in a water bath at $100{ }^{\circ} \mathrm{C}$ for $15 \mathrm{~min}$ and then centrifuged at $14,000 \mathrm{~g}$ for $10 \mathrm{~min}$. The supernatant was diluted $5 \times$ in millipore water and analysed using HPLC (Dionex DX300, Sunnyvale, CA, USA, ICS2500 system, detector range of $10 \mu \mathrm{S}$ ) using the column AS11 (ATC column+ guard column). Detection was with suppressed conductivity and the suppression

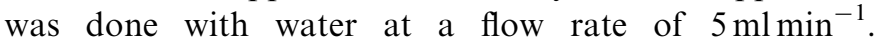
The eluent and the elution times used are as follows: 0-5 min $0.2 \mathrm{gl}^{-1} \mathrm{NaOH} ; 5-15 \mathrm{~min} \quad 0.2-4 \mathrm{gl}^{-1} \mathrm{NaOH}$; $15-20 \mathrm{~min} 20 \mathrm{gl}^{-1} \mathrm{NaOH}$ and $20-35 \mathrm{~min} 0.2 \mathrm{gl}^{-1} \mathrm{NaOH}$. A standard solution was prepared in millipore water, that contains $5.0 \mathrm{mgl}^{-1} \mathrm{NaNO}_{3}$ (Merck p.a.), $5.0 \mathrm{mgl}^{-1}$
$\mathrm{Na}_{2} \mathrm{SO}_{4}$ (Merck p.a.), $5.0 \mathrm{mg}^{-1}$ oxalic acid $\cdot 2 \mathrm{H}_{2} \mathrm{O}$ (Merck p.a.), $10.0 \mathrm{mgl}^{-1} \mathrm{Na}_{2} \mathrm{HPO}_{4} \cdot 2 \mathrm{H}_{2} \mathrm{O}$ (Merck 6346 p.a.), $10 \mathrm{mgl}^{-1}$ citric acid $\cdot \mathrm{H}_{2} \mathrm{O}$ (Merck K23524044 719 p.a.), $5.0 \mathrm{mgl}^{-1}$ cis-aconitate (Aldrich 27194-2) and $10 \mathrm{mgl}^{-1}$ $\mathrm{IP}_{6}$. $\mathrm{Na}_{12}$ (Sigma P3168 lot 102K0053). Measurements were performed in triplicate.

\subsubsection{Total phenolics}

Total PC were extracted from $50 \mathrm{mg}$ of flour in $1.5 \mathrm{ml}$ of $\mathrm{HCl} /$ methanol $\left(10 \mathrm{mll}^{-1}\right)$ during $1 \mathrm{~h}$ under continuous stirring at room temperature. The mixture was centrifuged at $5000 \mathrm{~g}$ for $10 \mathrm{~min}$ and supernatant was removed. The pellet was re-extracted as described above and supernatants were pooled (Cai, Ejeta, \& Butler, 1995). PC were measured following the method of Singleton and Rossi (1965) modified as follows. To $300 \mu \mathrm{l}$ of extract, $4.2 \mathrm{ml}$ of distilled water, $0.75 \mathrm{ml}$ of Folin-Ciocalteu's reagent (Merck, Germany) and $0.75 \mathrm{ml}$ of sodium carbonate solution $\left(200 \mathrm{gl}^{-1}\right)$ were added. After incubation for 30 min the optical density was measured at $760 \mathrm{~nm}$ using a spectrophotometer (Shimadzu UV 240, Kyoto, Japan). Blanks were also prepared in which Folin-Ciocalteu's reagent was replaced by water to correct for interfering compounds. Gallic acid (Acros Organics, New Jersey, USA) was used as standard and the results were expressed as gallic acid equivalent per gram of sample dry matter. Blanks were always freshly prepared.

\subsubsection{Data analysis}

For the analytical data, mean values and standard deviation are reported. The data were analysed using the statistical program SPSS 11.0 and the one-way ANOVA model was used applying the LSD test to evaluate significant difference among means.

\section{Results and discussion}

\subsection{Microbiological characteristics}

Tchoukoutou beer has a $\mathrm{pH}$ of $3.2 \pm 0.2$, resulting in a sour taste. The average level of titratable acidity amounted to $8 \pm 1$ (expressed as $\mathrm{g}^{-1}$ lactic acid equivalent). The major microorganisms involved in the fermentation of the beverage are LAB and yeasts (Table 1). Although the microbiological attributes of Beninese opaque beers were not investigated before, it was reported that the frequency distribution of microbial species isolated from African opaque beers may depend on localities and brewing ingredients (Demuyakor \& Ohta, 1991; Ekundayo, 1969; Faparusi, Olofinboba, \& Ekundayo, 1973; Nout, 1980; Odunfa, 1985; Sanni \& Lönner, 1993; Sefa-Dedeh, Sanni, Tetteh, \& Sakyi-Dawson, 1999). In the present study, we proceeded to a tentative characterization of yeasts and LAB involved in tchoukoutou using phenotypical characteristics.

Of 20 bacterial isolates, 15 were confirmed as LAB being Gram-positive, oxydase and catalase negative and 
Table 1

$\mathrm{pH}$, titratable acidity and major groups of microorganisms $(\log \mathrm{cfu} / \mathrm{ml})$ in tchoukoutou

\begin{tabular}{llcc}
\hline & Processor 1 & Processor 2 & Processor 3 \\
\hline $\mathrm{pH}$ & 3.0 & 3.5 & 3.1 \\
Titratable acidity as & 5.0 & 8.0 & 6.0 \\
lactic acid $\left(\mathrm{g} \mathrm{kg}^{-1}\right)$ & & & \\
Total count & nd & 8.2 & 7.8 \\
Yeast & 8.5 & 7.9 & 7.8 \\
Lactic acid bacteria & nd & 7.9 & 7.6 \\
Enterobacteriacae & $<1$ & $<1$ & $<1$ \\
\hline
\end{tabular}

nd $=$ not determined; data represent averages of duplicate values.

rod-shaped. All, except one, produced gas from glucose after $24 \mathrm{~h}$ of incubation. Three could not grow at 15 and $45^{\circ} \mathrm{C}$ after 5 days and $24 \mathrm{~h}$ of incubation, respectively. On the basis of their phenotypical characteristics, the LAB isolated were found to belong exclusively to the genus Lactobacillus. They were mainly obligate heterofermentatives, i.e. $L b$. divergens ( $21 \%$ of all Lactobacillus spp.), $L b$. fermentum (13\%), Lb. bifermentans (13\%), Lb. fructivorans $(13 \%), L b$. viridescens $(13 \%)$, Lb. hilgardii $(13 \%), L b$. kandleri $(7 \%)$ and $L$ b. casei $(7 \%)$. Lactobacilli were also isolated from many other African opaque beers (Nout, 1980; Odunfa, 1985). Other genera of LAB previously isolated from sorghum beer include Leuconostoc mesenteroides and Lactococcus spp. in burukutu and pito (Ekundayo, 1969; Faparusi et al., 1973).

After preliminary microscopic confirmation, all 40 yeasts isolated were subjected to morphology, fermentation and assimilation tests. None of the isolates could ferment lactose whereas the majority fermented glucose $(100 \%$ of all isolates), sucrose (95\%) and raffinose (90\%). Only 5\% of the isolates assimilated nitrate, ethylamine or creatine, whereas $15 \%$ assimilated L-lysine. All isolates were ascomycetous yeasts as revealed by Diazonium Blue B test. On the basis of their fermentation profile and their nitrogen assimilation pattern the 40 yeasts could be grouped into five distinct clusters with the majority $(63 \%)$ present in one group which showed a metabolism profile typical of Saccharomyces spp.

Based on their assimilation of carbon compounds, 16 assimilation profiles were distinguished. All yeasts assimilated glucose and maltose $(100 \%), 42.5 \%$ assimilated sucrose, $23 \%$ assimilated raffinose and only $2.5 \%$ could assimilate trehalose. None of them assimilated arabinose, sorbitol and methyl- $\alpha$ D-glucopyranoside. On the basis of their phenotypic characteristics, the 40 yeasts were found to belong to Saccharomyces cerevisiae (68\%), Candida albicans (12.5\%), Torulaspora delbrueckii (7\%), Saccharomyces pastorianus (5\%), Candida kunwiensis (2.5\%), Dekkera anomala $(2.5 \%)$ and Candida etchellsii $(2.5 \%)$. Clearly, S. cerevisiae predominates in the Benin opaque sorghum beer. Our results resemble findings by Konlani, Delgenes, Moletta, Traore, and Doh (1996) who reported a prevalence of $55-90 \%$ for $S$. cerevisiae in sorghum beer from Togo and Burkina-Faso, two regions close to our study area. Van der Aa Kühle, Jespesen, Glover, Diawara, and Jakobsen (2001) also identified a large number (45\%) of the yeasts involved in the fermentation of opaque beers from Burkina-Faso and Ghana as $S$. cerevisiae.

For an isolate to be accepted as $S$. cerevisiae it must be able to assimilate glucose, sucrose, maltose, trehalose, raffinose and ethanol (Vaughan-Martini \& Martini, 1998). In the present study, even though many isolates could not assimilate all of these sugars, they were identified as S. cerevisiae. Demuyakor and Ohta (1991) and Van der Aa Kühle et al. (2001) also identified many isolates from Ghanaian and Burkina-Faso sorghum beers as $S$. cerevisiae, even though these microorganisms showed carbon assimilation profiles different from the taxonomical key proposed by Vaughan-Martini and Martini (1998). Like in our result, many of the isolates analysed by these authors were not able to assimilate sucrose, raffinose and trehalose.

\subsection{Impact of process operations on total Fe and Zn content}

The impact of process unit operations on $\mathrm{Fe}$ and $\mathrm{Zn}$ content of grain and subsequent products is presented in Table 2. The Fe content of the sorghum grain found in this study $\left(947.5 \mathrm{mg} \mathrm{kg}^{-1}\right)$ is very high when compared to our previous findings (data not shown) in which $\mathrm{Fe}$ values range from 32 to $99 \mathrm{~m} \mathrm{~kg} \mathrm{k}^{-1}$ in 45 sorghum genotypes from Northern Benin. Jambunathan (1980) reported an average Fe content of $59 \mathrm{mg} \mathrm{kg}^{-1}$ with a range of $26-96 \mathrm{mg} \mathrm{kg}^{-1}$ in samples of about 100 varieties of sorghum. The origin of our grain which was bought at a local market may be responsible for this high Fe level. The grain may have been contaminated during the post-harvesting treatments notably during the threshing which consist of beating the ears on the ferruginous soil type (Kayodé et al., unpublished data). After soaking, the $\mathrm{Fe}$ content of the grain was significantly reduced by $61 \%$ of the initial value. Other investigators reported that up to $40 \%$ of $\mathrm{Fe}$ content of sorghum grain may be lost as a result of leaching in soaking medium (Lestienne, Icard-Vernière, Mouquet, Picq, \& Trèche, 2005). There was no significant effect of soaking on $\mathrm{Zn}$ content of the grain. The levels of Fe and $\mathrm{Zn}$ were not affected by the germination process. In contrast, significant losses of minerals resulted from mashing and filtration where $70 \%$ and $50 \%$ losses of $\mathrm{Fe}$ and $\mathrm{Zn}$ were recorded, respectively (Table 3 ). These losses could be related to overall losses of dry matter which was reduced by $40 \%$ after mashing/filtration. As a fraction of dry matter (Table 2), the levels of $\mathrm{Fe}, \mathrm{Zn}$, ash and crude protein have almost doubled after fermentation. However, Table 3 shows that in absolute terms, no significant changes in $\mathrm{Fe}$ and $\mathrm{Zn}$ levels take place. The apparent doubling effect in Table 2 is most likely due to shifts in dry matter composition, resulting from removal of spent grains and the assimilation of sugars and other fermentable mass. 


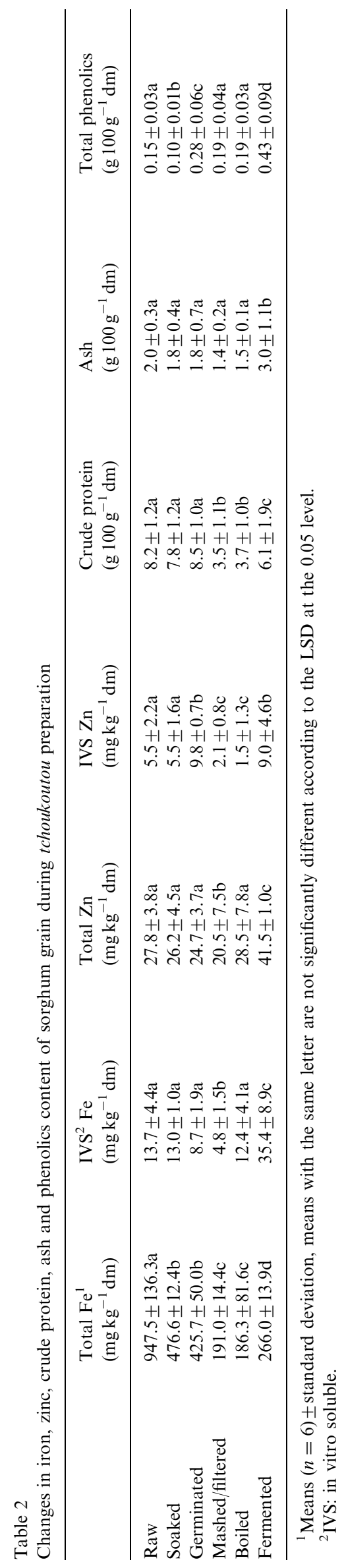

Table 3

Balances of mass, $\mathrm{Fe}$ and $\mathrm{Zn}$ during tchoukoutou preparation

\begin{tabular}{lccl}
\hline & Mass $(\mathrm{kgdm})$ & Fe $(\mathrm{g} \mathrm{dm})$ & $\mathrm{Zn}(\mathrm{g} \mathrm{dm})$ \\
\hline Raw & $100.0 \pm 0.0 \mathrm{a}$ & $94.7 \pm 40.9 \mathrm{a}$ & $2.8 \pm 0.4 \mathrm{a}$ \\
Soaked & $94.9 \pm 2.9 \mathrm{a}$ & $47.8 \pm 13.0 \mathrm{~b}$ & $2.6 \pm 0.3 \mathrm{ab}$ \\
Germinated & $80.7 \pm 6.5 \mathrm{~b}$ & $33.8 \pm 44.0 \mathrm{~b}$ & $2.0 \pm 0.4 \mathrm{~b}$ \\
Mashed/filtered & $47.9 \pm 13.0 \mathrm{c}$ & $10.2 \pm 8.0 \mathrm{c}$ & $1.0 \pm 0.6 \mathrm{c}$ \\
Boiled & $44.1 \pm 9.0 \mathrm{c}$ & $9.1 \pm 6.0 \mathrm{c}$ & $1.2 \pm 0.3 \mathrm{c}$ \\
Fermented & $23.1 \pm 1.4 \mathrm{~d}$ & $6.6 \pm 3.0 \mathrm{c}$ & $1.0 \pm 0.6 \mathrm{c}$ \\
\hline
\end{tabular}

Means $(n=6) \pm$ standard deviation, means with the same letter are not significantly different according to the LSD at the 0.05 level.

\subsection{Impact on phytate and total phenolics content}

The phytate content of the three sorghum batches used

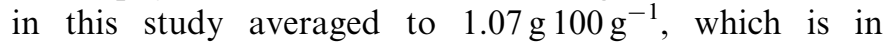
agreement with previous findings (Kayodé et al., 2005; Reddy, 2002; Traoré et al., 2005). Soaking, germination, mashing, boiling and fermentation strongly reduced the phytate content (Fig. 1). In total, only $5 \%$ of the initial phytate remained in the final beer. The magnitude of reduction induced by soaking in this study can be explained by the leaching in soaking medium or by partial hydrolysis by endogenous phytase as reported by Mahgoub and Elhag (1998).

Germination activates endogenous grain phytase which can degrade phytate (Svanberg \& Lorri, 1997). Hence, the phytate reduction induced by germination in this study, is presumably due to endogenous enzyme activity. Traoré et al. (2005) reported a 53\% reduction in sorghum grainphytate after germinating the seed for $74 \mathrm{~h}$, which is of a similar order of magnitude as observed by us. Even though some studies demonstrated that cooking does not degrade phytate in flour from sorghum (Kayodé et al., 2005) and other crops like pearl millet (Zanabria, Nienaltowska, de Jong, Hasenack, \& Nout, in press), our results showed a considerable reduction $(55 \%)$ of phytate content after boiling. This most likely relates to heat activation of residual phytase produced during germination, and the overnight souring (fermentation) that preceeds the boiling step.

The phytate reduction achieved by the fermentation in the present study was as expected since LAB and yeasts, particularly $S$. cerevisiae can produce phytase and degrade phytate into its lower forms, i.e. IP5 (inositol-pentakisphosphate), IP4, etc., and inorganic ortho-phosphate (Pi) that is used by these microorganisms for their growth (Andlid, Veide, \& Sandberg, 2004; Kerovuo \& Tynkkynen, 2000). In addition, the fermentation process would provide the optimum $\mathrm{pH}$ for the activity of phytase which is in the range pH 4.5-5.0 (Svanberg \& Lorri, 1997). The total reactive phenolic hydroxyl groups significantly increase

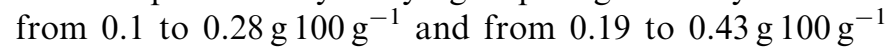
after germination and fermentation, respectively (Table 2). This increase may be expected as a result of a shift in dry 


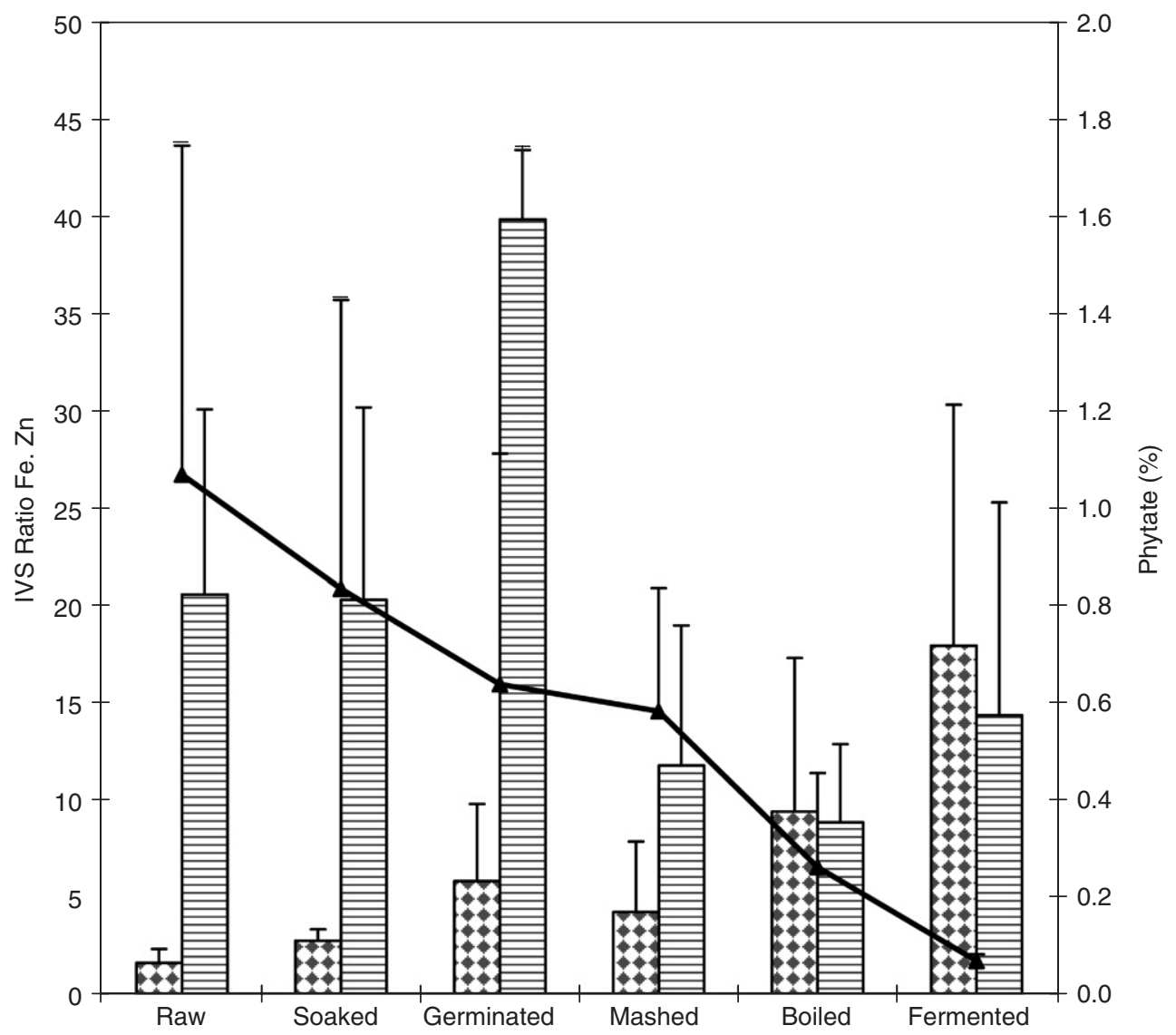

Fig. 1. Changes in phytate (IP6), in vitro soluble ratio Fe (IVS ratio Fe) and IVS ratio Zn during opaque sorghum beer preparation. The symbol (ム) represents phytate; represents IVS Fe and (目) represents IVS Zn; IVS ratio $=\left(\right.$ IVS total $\left.^{-1}\right) \times 100$.

matter composition mentioned earlier, as well as the hydrolysis of condensed PC due to germination and fermentation.

\subsection{Impact on in vitro solubility of $\mathrm{Fe}$ and $\mathrm{Zn}$}

The levels of soluble $\mathrm{Fe}$ and $\mathrm{Zn}$ at each processing stage are presented in Table 2. The total soluble $\mathrm{Fe}$ increased from $13.7 \mathrm{mg} \mathrm{kg}^{-1}$ in the raw grain to $35.4 \mathrm{mg} \mathrm{kg}^{-1}(\mathrm{dm})$ in the finished beer. The soluble $\mathrm{Zn}$ reached $9.0 \mathrm{mg} \mathrm{kg}^{-1}(\mathrm{dm})$ in the beer. Concomitantly with phytate degradation, the in vitro soluble $\mathrm{Fe}$ increases significantly at all process steps to reach $18 \%$ of total $\mathrm{Fe}$ after fermentation (Fig. 1). A significant negative correlation $(P<0.01)$ was observed between Fe solubility and the phytate content (Table 4). Phytate (myo-inositol hexakis phosphate, IP6) is the major inhibitor of $\mathrm{Fe}$ and $\mathrm{Zn}$ absorption from plant foods, and lowering the content of phytic acid in meals of plant origin greatly improves the absorption of these minerals (Frossard, Bucher, Mächler, Mozafar, \& Hurrell, 2000). Contrary to expectation, changes in $\mathrm{Zn}$ solubility during the process could not be linked to phytate variations. However, significant responses in $\mathrm{Zn}$ solubility were observed after germination and fermentation (Fig. 1). This appears to be associated with the changes taking place in total PC
Table 4

Pearson correlation matrix between IVS Fe, IVS Zn, phytate (IP6), proteins and phenolics compounds of sorghum

\begin{tabular}{lclrl}
\hline & Proteins & PC & IVS Zn & IVS Fe \\
\hline PC $^{\mathrm{a}}$ & -0.094 & & & \\
IVS $^{\mathrm{b}} \mathrm{Zn}$ & $0.829^{*}$ & 0.244 & & \\
IVS Fe $_{\text {IP6 }}^{-0.288}$ & $0.858^{*}$ & -0.088 & \\
\hline
\end{tabular}

${ }^{*}$ Correlation is significant at the 0.05 level.

** Correlation is significant at the 0.01 level.

${ }^{a} \mathrm{PC}$ : total phenolics compounds.

${ }^{\mathrm{b}}$ IVS: in vitro solubility.

as was mentioned earlier. The total PC significantly correlated with the Fe solubility: the higher the level of phenolic hydroxyl groups, the higher the soluble Fe. This finding corresponds with our previous observation in porridge cooked from sorghum flour in which a decrease in phenolic hydroxyl groups, probably due to complex formation or polymerization into condensed phenolics, was associated with a reduction of in vitro soluble Fe (Kayodé et al., 2005).

The significant correlation $(P<0.05)$ found between crude protein and soluble $\mathrm{Zn}$ (Table 4) may relate to the 
presence of $\mathrm{Zn}$ in a large number of enzymes and other proteins throughout the seed (Lestienne et al., 2005).

\section{Conclusion}

Soaking, germination, mashing as well as fermentation significantly contribute to phytate degradation during the beer making process. The total PC were modified as the result of germination and fermentation. Fe solubility gradually increases during the beer making process and is highly correlated with phytate and reactive phenolic groups in the product. However, important losses of minerals occurred during the beer making process, particularly during the mashing step; thus, the quantity of Fe available to consumers is restricted. No clear relationship could be established between the soluble $\mathrm{Zn}$ and the phytate content. Like in many African beers $S$. cerevisiae and Lactobacillus spp. are the predominant yeasts and LAB in the Benin opaque beer tchoukoutou. Further studies will focus on the optimization of germination and fermentation processes to improve $\mathrm{Fe}$ and $\mathrm{Zn}$ availability to consumers.

\section{Acknowledgement}

Financial support provided by Wageningen University through the North-South Interdisciplinary Research and Education Fund (INREF) is gratefully acknowledged. The International Foundation for Science, Stockholm, Sweden is acknowledged for financial support to A.P.P. Kayodé (Grant No. IFS E/3736-1).

\section{References}

Agu, R. C., \& Palmer, G. H. (1998). A reassessment of sorghum for lagerbeer brewing. Bioresearch Technology, 66, 253-261.

Andlid, T. A., Veide, J., \& Sandberg, A.-S. (2004). Metabolism of extracellular inositol hexaphosphate (phytate) by Saccharomyces cerevisiae. International Journal of Food Microbiology, 97, 157-169.

Bentsink, L., Yuan, K., Koornneef, M., \& Vreugdenhil, D. (2003). The genetics of phytate and phosphate accumulation in seeds and leaves of Arabidopsis thaliana, using natural variation. Theoretical and Applied Genetics, 106, 1234-1243.

Briggs, D. E., Boulton, C. A., Brookes, P. A., \& Stevens, R. (2004). Native African beers. In Brewing: Science and practice (pp. 589-605). Cambridge, UK: Woodhead Publishing Ltd.

Bvochora, J. M., Danner, H., Miyafuji, H., Braun, R., \& Zvauya, R. (2005). Variation of sorghum phenolic compounds during the preparation of opaque beer. Process Biochemistry, 40, 1207-1213.

Cai, T., Ejeta, G., \& Butler, L. G. (1995). Screening for grain polyphenol variants from high-tanin sorghum somaclones. Theoretical and Applied Genetics, 90, 211-220.

Demuyakor, B., \& Ohta, Y. (1991). Characteristics of pito yeasts from Ghana. Food Microbiology, 8, 183-193.

Dossa, R. A. M., Ategbo, E. A. D., de Koning, F. I. H. A., van Raaij, J. M. A., \& Hautvast, J. G. A. J. (2001). Impact of iron supplementation and deworming on growth performance in preschool Beninese children. European Journal of Clinical Nutrition, 55, 223-228.

Ekundayo, J. A. (1969). The production of pito, a Nigerian fermented beverage. Journal of Food Technology, 4, 217-225.
Faparusi, S. I., Olofinboba, M. O., \& Ekundayo, J. A. (1973). The microbiology of burukutu beer. Zeitschrift für Allgemeine Mikrobiologie, 13, 563-568.

Frossard, E., Bucher, M., Mächler, F., Mozafar, A., \& Hurrell, R. (2000). Potential for increasing the content and bioavailability of Fe, Zn, and $\mathrm{Ca}$ in plants for human nutrition. Journal of the Science of Food and Agriciculture, 80, 861-879.

Gibson, R. S. (1994). Zinc nutrition in developing countries. Nutrition Research Reviews, 7, 151-173.

Graf, E. (1986). Chemistry and application of phytic acid: An overview. In E. Graf (Ed.), Phytic acid: Chemistry and application (pp. 1-21). Minneapolis, MN: Pilatus Press.

Haggblade, S., \& Holzapfel, H. (1989). Industrialization of Africa's indigenous beer brewing. In K. H. Steinkraus (Ed.), Industrialization of indigenous fermented foods (pp. 191-283). New York: Marcel Dekker Inc.

Hounhouigan, D. J., Nout, M. J. R., Nago, C. M., Houben, J. H., \& Rombouts, F. M. (1993). Microbiological changes in mawe during natural fermentation. World Journal of Microbiology \& Biotechnology, $10,410-413$.

Jambunathan, R. (1980). Improvement of the nutritional quality of sorghum and pearl millet. Food and Nutrition Bulletin, 2, 11-16.

Kayodé, A. P. P., Adégbidi, A., Linnemann, A. R., Nout, M. J. R., \& Hounhouigan, D. J. (2005). Quality of farmer's varieties of sorghum and derived foods as perceived by consumers in Benin. Ecology of Food and Nutrition, 44, 271-294.

Kerovuo, J., \& Tynkkynen, S. (2000). Expression of Bacillus subtilis phytase in Lactobacillus plantarum 755. Letters in Applied Microbiology, 30, 325-329.

Kiers, J. L., Nout, M. J. R., \& Rombouts, F. M. (2000). In vitro digestibility of processed and fermented soya bean, cowpea and maize. Journal of the Science of Food and Agriculture, 80, 1325-1331.

Konlani, S., Delgenes, J. P., Moletta, R., Traore, A., \& Doh, A. (1996). Isolation and physiological characteristics of yeasts involved in sorghum beer production. Food Biotechnology, 10, 29-40.

Kurtzman, C. P., Boekhout, T., Robert, V., Fell, J. W., \& Deak, T. (2003). Methods to identify yeasts. In T. Boekhout, \& V. Robert (Eds.), Yeasts in food: Beneficial and detrimental aspects (pp. 69-121). Hamburg: B. Behr's Verlag GmbH \& Co. KG.

Lestienne, I., Icard-Vernière, C., Mouquet, C., Picq, C., \& Trèche, S. (2005). Effect of soaking whole cereal and legume seeds on iron, zinc and phytate contents. Food Chemistry, 89, 421-425.

Mahgoub, S. E. O., \& Elhag, S. A. (1998). Effect of milling, soaking, malting, heat-treatment and fermentation on phytate level of four Sudanese sorghum cultivars. Food Chemistry, 61, 77-80.

Nout, M. J. R. (1980). Microbiological aspects of the traditional manufacture of Busaa, a Kenyan opaque maize beer. Chemie Mikrobiologie Technologie der Lebensmittel, 6, 137-142.

Novellie, L., \& De Schaepdrijver, P. (1986). Modern developments in traditional African beers. Progress in Industrial Microbiology, 23, 74-157.

Novozamsky, I., van Eck, R., Houba, V. J. G., \& van der Lee, J. J. (1996). Solubilization of plant tissue with nitric acid-hydrofluoric acid-hydrogen peroxide in a closed system microwave digestor. Communications in Soil Science and Plant Analysis, 27, 867-875.

Obizoba, I., \& Atii, J. V. (1991). Effect of soaking, sprouting, fermentation and cooking on nutrient composition and some antinutritional factors of sorghum (Guinesia) seeds. Plant Foods for Human Nutrition, 41, 203-212.

Odunfa, S. A. (1985). African fermented foods. In B. J. B. Wood (Ed.), Microbiology of fermented foods (pp. 167-195). London, UK: Elsevier Applied Science.

Oikeh, S. O., Menkir, A., Maziya-Dixon, B., Welch, R., \& Glahn, R. P. (2003). Assessment of concentrations of iron and zinc and bioavailable iron in grain of early maturing tropical maize varieties. Journal of Agricultural and Food Chemistry, 51, 3688-3694.

Reddy, N. R. (2002). Occurrence, distribution, content, and dietary intake of phytate. In N. R. Reddy, \& S. K. Sathe (Eds.), Food phytates (pp. 25-52). Boca Raton, FL: CRC Press. 
Sanni, A. I., \& Lönner, C. (1993). Identification of yeast isolated from Nigerian traditional alcoholic beverages. Food Microbiology, 10, $517-523$.

Sefa-Dedeh, S., Sanni, A. I., Tetteh, G., \& Sakyi-Dawson, E. (1999). Yeasts in the traditional brewing of pito in Ghana. World Journal of Microbiology and Biotechnology, 15, 593-597.

Singleton, V. L., \& Rossi, J. A. (1965). Colorimetry of total phenolic compounds with phosphomolybdic phosphotungstic acid reagents. American Journal of Enology and Viticulture, 16, 144-158.

Subramanian, V., Murty, D. S., Sambasiva, R. N., \& Jambunathan, R. (1992). Chemical changes and diastatic activity in grain of sorghum (Sorghum bicolor) cultivars during germination. Journal of the Science of Food and Agriculture, 58, 35-40.

Svanberg, U., \& Lorri, W. (1997). Fermentation and nutrient availability. Food Control, 8, 319-327.

Temminghof, E. (2000). Soil and plant analysis. Part 3. Plant analysis procedures. Wageningen: Wageningen University Environmental Sciences.
Traoré, T., Mouquet, C., Icard-Vernière, C., Traoré, A. S., \& Trèche, S. (2005). Changes in nutrient composition, phytate and cyanide contents and $\alpha$-amylase activity during cereal malting in small production units in Ouagadougou (Burkina Faso). Food Chemistry, 88, 105-114.

Van der Aa Kühle, A., Jespesen, L., Glover, R. L. K., Diawara, B., \& Jakobsen, M. (2001). Identification and characterization of Saccharomyces cerevisiae strains isolated from West African Sorghum beer. Yeast, 18, 1069-1079.

Vaughan-Martini, A., \& Martini, A. (1998). Saccharomyces Meyen ex Reess. In C. P. Kurtzman, \& J. W. Fell (Eds.), The yeasts, a taxonomic study (pp. 358-371). Amsterdam: Elsevier Science.

Wijtzes, T., Bruggeman, M. R., Nout, M. J. R., \& Zwietering, M. H. (1997). A computerised system for the identification of lactic acid bacteria. International Journal of Food Microbiology, 38, 65-70.

Zanabria, E. R., Nienaltowska, K., de Jong, L. E. Q., Hasenack, B. B. E., \& Nout, M. J. R. (in press). Effect of food processing of pearl millet (Pennisetum glaucum) IKMP-5 on the level of phenolics, phytate, iron and zinc. Journal of the Science of Food and Agriculture. 